\title{
Soviet Organizational Acronyms and Abbreviations
}

Agitmass

Agitpropotdel

Agitprop

AKhRR

AP

APPO TsK

ASM

ASNOVA

Cheka

Comintern
[Otdel] agitatsionno-massovoi raboty (Department of Agitational and Mass Work)

See Agitprop

Agitatsia i propaganda (Agitation and Propaganda; Department of Agitation and Propaganda of the Central Committee)

Assotsiatsia khudozhnikov revoliutsionnoi Rossii (Association of Artists of Revolutionary Russia) Assotsiatsia pisatelei (Association of Writers) Agitatsionno-propagandistsky podotdel TsK (Agitation and Propaganda Subsection of the Central Committee)

Assotsiatsia sovremennoi muzyki (Association of Contemporary Music)

Assotsiatsia novykh arkhitektorov (Association of New Architects; a Constructivist group)

Chrezvychainaia komissia ([All-Russian] Extraordinary Commission [for Combating Counterrevolution, Sabotage, and Speculation], I9I 822, succeeded by GPU)

Communist International 
xxiv

Detgiz

FOSP

GABT

GIKhL

GIZ

Glaviskusstvo

Glavlit

Glavpolitprosvet

Glavrepertkom

gorkom

Gosizdat

Goslitizdat

Gosplan

GOSTIM

GPU

GRK

GUGB

GUK

GULAG

IKP
Acronyms and Abbreviations

Gosudarstvennoe izdatel'stvo detskoi literatury (State Publishing House of Children's Literature) Federatsia Ob" edineny sovetskikh pisatelei (Federation of Unions of Soviet Writers)

Gosudarstvennyi akademichesky Bol'shoi teatr (State Academic Bolshoi Theater)

Gosudarstvennoe izdatel'stvo khudozhestvennoi literatury (State Publishing House for Literature) See Gosizdat

Glavnoe upravlenie iskusstva (Chief Directorate of Art)

Glavnoe upravlenie literatury (Chief Directorate of Literature; organ of literary censorship)

Glavnoe upravlenie politicheskogo prosveshchenia (Chief Directorate of Political Education)

Glavnyi repertuarnyi komitet (Main Repertoire Committee; organ of theater censorship) gorodskoi komitet (city committee of the Communist Party)

Gosudarstvennoe izdatel'stvo (State Publishing House)

Gosudarstvennoe izdatel'stvo khudozhestvennoi literatury (State Publishing House for Literature) Gosudarstvennyi komitet po planirovaniiu (State Planning Committee)

Gosudarstvennyi teatr imeni Meierkhol'da (Vs.

Meyerhold State Theater)

Gosudarstvennoe politicheskoe upravlenie (State

Political Administration; the secret police

[1922-32], successor to the Cheka)

See Glavrepertkom

Glavnoe upravlenie gosudarstvennoi bezopasnosti (Central Directorate of State Security) Gosudarstvennoe upravlenie kinematografii (State Administration of Cinematography) Gosudarstvennoe upravlenie lagerei (State Administration of Camps; the labor camp system)

Institut krasnoi professury (Institute of Red Professors) 
IMLI

Informburo

INO

ispolkom

Kogiz

kolkhoz

Komakademia

Komsomol

KPK

KPSS

krai

kraiobllit

KUBU

Kultprop

Kultpropotdel

Kultprosvet

Kultprosvetotdel

LEF

Lengorlit

Lengublit

Litfond

Litfront

LOKAF

MGSPSRT
Institut mirovoi literatury imeni Gor'kogo

(Gorky Institute of World Literature)

See Sovinformburo

Inostrannyi otdel (Foreign Department)

ispolnitel'nyi komitet (executive committee of a soviet)

Kooperativnaia organizatsia gosudarstvennykh izdatel'stv (Cooperative Organization of State

Publishing Houses)

kollektivnoe khoziaistvo (collective farm)

Kommunisticheskaia akademia (the Communist academy)

Kommunistichesky soiuz molodezhi (Communist Union of Youth)

Komitet partiinogo kontrolia (Party Control

Commission)

Kommunistichskaia partia Sovetskogo Soiuza

(Communist Party of the Soviet Union)

administrative territory roughly equivalent to

oblast

krai branch of Glavlit

Komitet po uluchsheniu byta uchenykh (Com-

mittee to Improve Scholars' Living Conditions)

Kul'turno-propagandistsky otdel (Department

for Culture and Propaganda)

See Kultprop

Kul'turno-prosvetitel'nyi otdel (Department for Cultural-Educational Work)

See Kultprosvet

Levyi front iskusstva (Left Front in the Arts)

Leningrad city branch of Glavlit

Leningrad province branch of Glavlit

Literaturnyi fond (Literary Fund, for assistance to writers)

Literaturnyi front (Literary Front)

Literaturnoe ob"edinenie Krasnoi Armii i Flota

(Literary Association of the Red Army and Navy)

Moskovsky gorodskoi sovet professional'nykh

soiuzov rabotnikov teatra (Moscow City Com-

mittee of Theater Workers Trade Unions) 
xxvi

MK

MKhAT

MOPR

MORP

Mosfilm

Mosgorlit

Mosgubispolkom

Mosgublit

MOSKh

Mosoblispolkom

MTS

Narkomat

Narkomindel

Narkomfin

Narkomprod

Narkompros

NEP

NKGB

NKID

NKP

NKRK

\section{Acronyms and Abbreviations}

Moskovsky komitet (Moscow Party Committee) Moskovsky khudozhestvennyi teatr (Moscow Art Theater) Mezhdunarodnaia organizatsia pomoshchi bortsam revoliutsii (International Organization for Assistance to Revolutionary Fighters, founded in I 922 by the Comintern)

Mezhdunarodnoe ob"edinenie revoliutsionnykh pisatelei (International Union of Revolutionary Writers)

Moscow Film Studio

a Moskovskoe gorodskoe upravelenie literatury (Moscow city branch of Glavlit)

See Mosoblispolkom

Moskovskoe gubernskoe upravlenie literatury (Moscow province branch of Glavlit) Moskovskoe ob"edinenie sovetskikh khudozhnikov (Moscow Association of Soviet Artists) Moskovskii oblastnoi ispolnitel'nyi komitet (Moscow Regional Executive Committee) Mashino-traktornaia stantsia (machine tractor station)

Narodnyi komissariat (People's Commissariat) See NKID

Narodnyi komissariat finansov (People's Commissariat of Finance)

Narodnyi komissariat prodovol'stvia (People's Commissariat of Production)

Narodnyi komissariat prosveshchenia (People's Commissariat of Enlightenment, i.e., of culture and education)

Novaia Ekonomicheskaia Politika (the New

Economic Policy), instituted in I92 I

Narodnyi komissariat gosudarstvennoi bezopasnosti (People's Commissariat for State Security) Narodnyi komissariat inostrannykh del (People's Commissariat of Foreign Affairs)

See Narkompros

Narodnyi komissariat raboche-krestianskoi inspektsii (People's Commissariat of Workers' and Peasants' Inspection) 
NKVD

NKVDNudel

NKVT

nomenklatura

$\mathrm{OB}$

Oberiu

obkom

oblast

oblit

Ogiz

OGPU

okrug

Orgburo

Orgkom

Osobotdel VChK

OST

Partkollegia

PB

Politburo

Politotdel

Proletkult

Rabis

Rabkor

raion

Raispolkom
Narodnyi komissariat vnutrennykh del (People's

Commissariat for Internal Affairs; from 1934 the successor to the OGPU)

See NKVD

Narodnyi komissariat vneshnei torgouli (People's Commissariat of Foreign Trade)

people chosen by the Party apparatus to serve in various responsible positions

acronym for Orgburo

Ob"edinenie real'nogo iskusstva (Association for Real Art)

oblastnoi komitet (oblast committee of the Communist Party)

administrative unit, region

an oblast administration for Glavlit

Ob"edinennoe gosudarstvennoe izdatel'stvo

(Amalgamated State Publishing House)

Ob"edinennoe gosudarstvennoe politicheskoe upravlenie (Unified State Political Administration; the secret police [1932-34], successor to the GPU) an administrative unit between the raion and the oblast

Organizatsionnoe biuro (Organizational Bureau)

Organizatsionnyi komitet (Organizational Committee)

Osobyi otdel VChK (Special Department of the Cheka)

Obshchestvo stankovistov (Society of Easel Painters)

Partiinaia kollegia (Collegium of the Party) acronym for Politburo

Political Bureau of the Central Committee

Political Department

Proletarian Culture, a cultural organization

Profsoiuz rabotnikov iskusstva (Union of Arts

Workers)

Rabochy korrespondent (worker correspondent)

administrative unit, between okrug and oblast in

size

Raionny ispolnitel'nyi komitet (District Execu-

tive Committee) 
xxviii

RAPM

RAPP

Repertkom

RK

RKI

RKKA

RKP

ROPKP

ROSTA

$\operatorname{RSDRP}(b)$

RSFSR

Sanprosvet

SNK SSSR

Sovinformburo

sovkhoz

Sovnarkom

SPO

SR

SSP SSSR

TASS
Acronyms and Abbreviations

Rossiiskaia Assotsiatsia Proletarskikh Muzykantov (Russian Association of Proletarian Musicians)

Rossiiskaia Assotsiatsia Proletarskikh Pisatelei (Russian Association of Proletarian Writers) See Glavrepertkom Raionnyi komitet (District Committee) Raboche-krestianskaia inspektsia (Worker-Peasant Inspection)

Raboche-krestianskaia krasnaia armia (WorkerPeasant Red Army)

Rossiiskaia kommunisticheskaia partia (Russian Communist Party)

Rossiiskaia assotsiatsia proletarsko-kolkhoznykh pisatelei (Russian Association of Proletarian Kolkhoz Writers)

Rossiiskoe telegrafnoe agentstvo (Russian Telegraph Agency)

Rossiiskaia sotsial-demokraticheskaia partia (bol'shevikov) (Russian Social Democratic Workers Party [Bolsheviks]) Rossiiskaia Sovetskaia Federativnaia Sotsialisticheskaia Respublika (Russian Soviet Federative Socialist Republic)

Sanitarnoe prosveshchenie (Sanitary Enlightenment)

Sovet narodnykh komissarov SSSR (Council of People's Commissars of the USSR)

Sovetskoe informatsionnoe biuro (Soviet Information Bureau) sovetskoe khoziaistvo (state farm employing wage labor)

See SNK SSSR Spetsial'nyi politichesky Otdel (Special Political Department of the secret police) Socialist Revolutionaries Soiuz sovetskikh pisatelei SSSR (Union of Soviet Writers of the USSR) Telegrafnoe agentstvo Sovetskogo Soinza (Telegraph Agency of the Soviet Union) 
Torgprom

TRAM

TsDKA

TsIK

TsKK

TsK RKP(b)

TsK VKP(b)

UNKVD

VAPP

VChK

VLKSM

VOAPP

VOKP

VOKS

VSNKh

VSP

VSSP

VTsIK
Torgovaia promyshlennost' (retail industry) Teatr rabochei molodezhi (Theater of Worker Youth)

Tsentral'nyi dom Krasnoi armii (M. V. Frunze Central House of the Red Army)

See VTsIK

Tsentral'naia kontrol'naia komissia (Central

Control Commission of the Party)

Tsentral'nyi komitet Rossiiskoi kommunisticheskoi partii (bol'shevikov) (Central Committee of the Russian Communist Party [Bolsheviks])

Tsentral'nyi komitet Vsesoiuznoi kommunisticheskoi partii (bol'shevikov) (Central Committee of the All-Union Communist Party [Bolsheviks]) Upravlenie Narodnogo komissariata vnutrennikh del (People's Commissariat of Internal Affairs Administration)

Vsesoiuznaia Assotsiatsia Proletarskikh Pisatelei (All-Union Association of Proletarian Writers) Vsesoiuznaia chrezvychainaia komissia (AllUnion Extraordinary Commission; see Cheka) See Komsomol Vsesoiuznoe Ob"edinenie Assotsiatsii Proletarskikh Pisatelei (All-Union Alliance of Proletarian Writers Associations)

Vserossiiskoe ob"edinenie krest'ianskikh pisatelei (All-Russian Union of Peasant Writers) Vsesoiuznoe obshchestvo kul'turnykh sviazei s zagranitsei (All-Union Society for Cultural Relations with Abroad)

Vsesoiuznyi sovet narodnogo khoziaistva (AllUnion Council of the National Economy) Vserossiisky soiuz pisatelei (All-Russian Union of Writers)

Vserossiisky soiuz sovetskikh pisatelei (All-Russian Union of Soviet Writers) Vsesoiuznyi tsentral'nyi ispolnitel'nyi komitet (All-Union Central Executive Committee [of soviets]) 
VTsSPS

Vsesoiuznyi tsentral'nyi sovet professional'nykh soiuzov (All-Union Central Board of Trade Unions)

VUSPP Vseukrainsky soiuz proletarskikh pisatelei (AllUkrainian Association of Proletarian Writers)

Zhurgaz Zhurnal'no-gazetnoe ob"edinenie (journal and newspaper conglomerate) 
and discussions of the Soviet Politburo and of the Secretariat of the Central Committee of the Soviet Communist Party, documents prepared by members of the Central Committee's departments responsible for making decisions on cultural matters, petitions and letters from intellectuals to Stalin and to other members of the leadership, and reports from the secret police (successively named the VChKA or Cheka, GPU, OGPU, and NKVD) detailing reactions among intellectuals to certain high-level decisions. They largely came from closed archives that even today remain inaccessible to most scholars, let alone the general public: the Archive of the President of the Russian Federation (AP RF), the Russian Archive of Contemporary Political History (RGASPIthe former Party archive and archive of the Comintern), the Central Archive of the Federal Security Service of the Russian Federation (i.e., the secret police-TsA FSB RF), the Russian State Archive of Literature and Art (RGALI), and the archive of the Gorky Institute of World Literature (IMLI).

Thus these documents provide the sort of information on which scholars writing on Soviet cultural history have until recently only been able to speculate. They not only fill in many lacunae in our knowledge of the dynamic of Soviet cultural history, of the workings of its institutions, and of the biographies of individual intellectuals and leaders, but also in many instances correct the standard accounts of how certain decisions were made in the cultural sphere, and of the mechanisms of decision making in general. They also bring to light the political underpinnings of particular events which scholars had previously been at a loss to explain.

Above all, the documents presented here on the activities of the Politburo oblige scholars to revise the standard accounts of "the Party's interference in the cultural sphere" and of the degree of its interference. One can even argue that to talk in terms of "interference" is to formulate the issue incorrectly. The Party leadership did not "interfere" inasmuch as it was the body charged with regulating all matters of the Soviet state, including cultural ones. Indeed, Soviet power could be described as a mechanism whereby nothing could function without decisions being made by Party bodies. In consequence, and as became evident during the Gorbachev era of perestroika (reform), the Soviet system turned out to be unreformable: it was simply unable to function without Party-cum-state regulation.

In these documents we come to appreciate the tremendous role that the highest Party bodies played in the cultural sphere. By these "high- 